\section{Impact of speciation on behaviour of uranium in a solar powered membrane system} for treatment of brackish groundwater

Helfrid M.A. Rossiter ${ }^{\mathrm{a}}$, Margaret C. Graham ${ }^{\mathrm{b}}$ and Andrea I. Schäfer ${ }^{\mathrm{a}^{*}}$

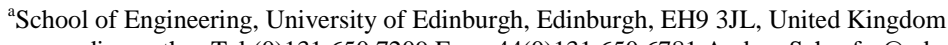
*Corresponding author Tel (0)131 6507209 Fax +44(0)1316506781 Andrea.Schaefer@ed.ac.uk ${ }^{b}$ School of Geosciences, University of Edinburgh, Edinburgh, EH9 3JN, United Kingdom

\section{Published in}

Journal of Separation and Purification Technology 71 (2010) 89-96

\section{Abstract}

Factors affecting uranium removal from brackish groundwater using a direct solar powered ultrafiltration-nanofiltration/reverse osmosis membrane system were investigated during a field trial in the Australian outback. The key variables were uranium speciation (as a function of $\mathrm{pH}$ ), was found that uranium was retained by the membranes over the $\mathrm{pH}$ range 3-11, but strongly adsorbed to membranes at $\mathrm{pH}$ 4-7. The speciation of uranium $\mathrm{pH}$ 4-7 explained the adsorption to the membrane. The presence of other inorganic species, in particular calcium, was a likely cause of uranium co-precipitation at $\mathrm{pH}$ 10-11. During solar energy experiments, it was found that the specific energy consumption increased over the course of the day. This indicated fouling through precipitation on the membranes which caused reduced retention of uranium towards the end of the solar day.

Keywords: Nanofiltration, reverse osmosis, renewable energy, uranium, decentralised treatment.

\section{Introduction}

Groundwater is generally perceived as a safe drinking water alternative to surface water, especially in developing countries, and is therefore often left untreated [1]. However, groundwate may contain high levels of inorganic contaminants which put millions of people worldwide at risk of chronic poisoning [2]. Uranium is present naturally in the Earth's crust at an average concentration of $2.7 \mu \mathrm{g} / \mathrm{g}$ and in sea water at a concentration of about $3.3 \mu \mathrm{g} / \mathrm{L}$. Higher levels of up to $15 \mu \mathrm{g} / \mathrm{g}$ and $120 \mu \mathrm{g} / \mathrm{g}$ may occur in granite and phosphate rocks, respectively [3]. Consequently, uranium can also be released into groundwater through weathering of these materials, and so concentrations will vary depending on local geology and water source. Anthropogenic activities such as mining and milling of uranium ores and other minerals, nuclear power and weapons production, phosphate fertiliser production and use of depleted uranium may also have an adverse impact on groundwater concentrations [3-5]. As well as being naturally radioactive, uranium is above all chemically toxic and may replace calcium in bones and cause kidney damage or even failure when ingested in high concentrations [6,7]. Levels of uranium of $1 \mathrm{mg} / \mathrm{kg}$ of kidney have (compared to e.g. $6 \mathrm{mg} / \mathrm{kg}$ for arsenic) [9]. Although the effects of chronic uranium exposure are less well-established than those for other elements such as arsenic, the World Health Organisation (WHO) provisional drinking water guideline is set to $15 \mu \mathrm{g} / \mathrm{L}$, based on the tolerable daily intake of the element [10].

An element's oxidation state often determines its chemical behaviour in terms of environmental mobility and bio-availability. Uranium has several oxidation states: +III to +VI, of which +IV (uranous) and +VI (uranyl) are the most common in the natural environment. In oxic groundwaters $\mathrm{U}(\mathrm{VI}) \mathrm{O}_{2}{ }^{2+}$ is found under acidic conditions [3] whilst a range of $\mathrm{U}(\mathrm{VI})$ complexes are formed under conditions of increasing basicity. Some important ligands for uranyl ion complex formation are carbonate, hydroxide and dissolved organic matter. Carbonate generally outcompetes hydroxyl ligands, thereby increasing the uranium solubility in waters exposed to the atmosphere at neutral and alkaline $\mathrm{pH}$ [3]. Under reducing groundwater conditions and in the solid phase, uranium is present predominantly as $\mathrm{U}(\mathrm{IV})$.

In areas of high groundwater uranium concentrations such as central Australia or parts of USA [3], there is a need to remove uranium before the water is used for human consumption. Membrane technology, namely nanofiltration (NF) and reverse osmosis (RO), has been highly successful in the removal of uranium from drinking water [11], contaminated groundwater, soil and (U), with its inherent higher size cit-off values, has been used [15]. NF and RO, hower, ar advantageous fo direct groundwater treatment and Raff and Wilken [16] found that $81-99 \%$ uranium could be rejected simply using NF. More recently Favre-Reguillion et al. [17] investigated the selectivity of $\mathrm{NF}$ membranes and found that high retention of uranium could be achieved while allowing passage of important trace minerals. In addition, they emphasized the importance of membrane selection and determination of operating parameters in order to optimise desired rejection values whilst minimising both energy consumption and negative effects such as concentration polarisation at the membrane surface.

The performance of a solar powered membrane system the system [18] has previously been evaluated under fluctuating solar energy [19] and for removal of inorganic contaminants [20]. This paper specifically investigates the behaviour or uranium as a function of $\mathrm{pH}$. While $\mathrm{pH}$ varies greatly in natural waters (a range of 3 to 10 has been reported [3]), the impact of uranium speciation on its behaviour in membrane filtration is to date unknown. The effect of the varying solar energy on the retention of uranium over the course of a day was also investigated as operating parameters fluctuate with solar irradiance.

\section{Materials and methods}




\subsection{Solar powered membrane system}

Details of the solar powered hybrid membrane system (submerged UF and NF/RO) were published by Schäfer et al. [18]: however a flow diagram of the membrane set-up is given in Figure 1. Experiments conducted at constant energy to study the effects caused by varying $\mathrm{pH}$ were followed by solar experiments to investigate system behaviour with fluctuating energy. The system does not use batteries for energy storage and consequently any energy fluctuation resulted in variations in operating flow and pressure.

\section{[Figure 1]}

\subsection{Groundwater chemistry: $\mathrm{pH}$ experiments}

Experiments to investigate the effect of $\mathrm{pH}$ on trace contaminant retention were performed with constant power supply over the $\mathrm{pH}$ range 3-11. In this paper, the results of five such $\mathrm{pH}$ experiments are presented from two locations in the Northern Territory in Australia; one at Ti Tree Farm using a BW30 membrane (Filmtec), and four at Pine Hill using the following NF/RO membrane types of different salt retention [18], namely NF90 (Filmtec), ESPA4 (Hydranautics), TFC-S (Koch Membrane Systems) and BW30 (Filmtec) (see Table S1 in Supporting Information for more details on membrane characteristics). The UF membrane used for all experiments was Zenon ZW10 (GE Water and Process Technologies), six modules in parallel with a total surface area of $5.58 \mathrm{~m}^{2}$. The feed $\mathrm{pH}$ was adjusted with $\mathrm{NaOH}$ or $\mathrm{HCl}$ (analytical grade, Fisher Scientific) and performance allowed to equilibrate before taking samples (typically $30-60$ minutes). The feed pressure was set to $9 \mathrm{bar}$ and the feed flow to $400 \mathrm{~L} / \mathrm{h}$ [20]. The temperature was reasonably stable during the individual experiments (Figure S1). Samples were taken of the feed, UF permeate, concentrate and $\mathrm{NF} / \mathrm{RO}$ permeate solutions. $\mathrm{NF} / \mathrm{RO}$ permeate (referred to as simply permeate hereafter) and concentrate solutions were re-circulated back to the feed tank. Conductivity, $\mathrm{pH}$ and measurements (Multiline P4 millimetre, WTW) were taken throughout the experiments.

\subsection{Solar energy experiments}

Experiments were conducted as described by Richards et al. [19] to investigate performance of the system in terms of producing good quality drinking water under natural solar energy variation. A solar batch experiment was conducted at Pine Hill using a BW30 membrane, where permeate and concentrate solutions were re-circulated back to the feed (Figure 1). A sola continuous experiment was conducted at Pine Hill again using the BW30 membrane. In this case the war was not re-circulated and he feed tank was contingur the solar batch and solar continuous experiment, the pressure increased with solar radiance, starting at 4 bar and stabilised at about 11 bar once the radiance reached its maximum, while the feed flow stabilised to about $400 \mathrm{~L} / \mathrm{h}$ (Figure S3). Samples were taken at least hourly and the experiment conducted throughout the solar day (12 hours).

\subsection{Chemical analysis}

Samples were filtered and acidified with $\mathrm{HNO}_{3}(1 \% \mathrm{v} / \mathrm{v}$, sub-boiled) for cation analysis while part of the sample was kept un-acidified for anion analysis. Samples from the $\mathrm{pH}$ experiments were ant of the sy ANTO (Australian Nuclear Science and Technology Organis (L) (C) (Varian Vista AX simultaneous CCD). Samples for ICP-MS (Agilent 4500) were spiked with internal standards, In, Y, $\mathrm{Li}, \mathrm{Sc}, \mathrm{Lu}, \mathrm{Bi}$ and $\mathrm{Rh}$, which were used to correct for variations in instrument sensitivity. Anions were analysed by IC (Dionex DX-600 with EG40 Eluent Generator) by ANSTO. For the solar experiments the trace elements were analysed at using by ICP-MS (Agilent 7500ce). The calibration was verified using a certified reference material (ICP Mult Element Standard Solution VI CertiPUR), and the instrument stability throughout the run was monitored by inserting check standards every 10 samples.

\subsection{Speciation modeling}

Uranium speciation was calculated using the speciation software Visual Minteq $2.53(\mathrm{KTH}$, Stockholm, Sweden), which was updated in October 2007, and includes a major review on thermodynamic data on uranium. This is based on the database used in MinteqA2 [21] which incorporated thermodynamic data from Grenthe et al. [22], but has since been revised by Guillaumont et al. [23], and is Development - Nuclear Energy Agency) database. Elemental concentration data for each $\mathrm{pH}$ value were entered for an initial model calculation to give the most important species with respect to uranium complexation. Elemental oxidation states of the elements were selected according to general groundwater conditions [3] and consultation of phase diagrams. The speciation was then carried out by doing a sweep test on the selected species. The temperature was set to $25^{\circ} \mathrm{C}$ and the $\mathrm{CO}_{2}$ pressure was set to atmospheric pressure (partial pressure $3.9 \times 10^{-4}$ bar) as the groundwater was in contact with air during the experiment. The resulting charge difference in the anion and cation balance was 5.5\% for Ti Tree Farm and 3.9\% for Pine Hill. The influence of reducing or oxidising conditions, based on the expected range for these waters, was also tested in Minteq, but did not affect the predicted uranium speciation.

\subsection{Membrane performance modeling}

RoPro 7.0 software (Koch Membrane Systems) was used to simulate the system under the given experimental conditions. Chemical composition of permeate and concentrate streams, as well as calculation of the saturation index (SI) of five compounds $\left(\mathrm{CaSO}_{4}, \mathrm{BaSO}_{4}, \mathrm{SrSO}_{4}, \mathrm{CaF}_{2}\right.$ and $\mathrm{SiO}_{2}$ ) as a function of flow and pressure were calculated. The single-pass design option was selected and the parameters entered were feed composition, $\mathrm{pH}$, water type (brackish well water), inlet pressure $(8.7 \mathrm{bar}$ in the TFC-S experiment for Pine Hill, while the solar continuous experiments varied from 4-11 bar) and membrane information ( 1 pressure vessel, 1 element). As the software only includes Koch membranes, simulations were performed with the TFC-S membrane and TSC-XR (for comparison with a high retention membrane).

\section{Results and discussion}

The concentration of uranium found in the groundwater was $25 \mu \mathrm{g} / \mathrm{L}$ for Ti Tree Farm and about $295 \mu \mathrm{g} / \mathrm{L}$ at Pine Hill station. These values are both above the Australian Drinking Water Guideline (ADWG) and the WHO guideline values for uranium, which are 20 and $15 \mu \mathrm{g} / \mathrm{L}$, respectively. A detailed analysis of the retention of the different ions in the waters was reported by Richards et al. [20].

\subsection{Retention of monovalent and divalent ions}

The retention of selected mono $\left(\mathrm{Cl}^{-}, \mathrm{K}^{+}\right.$and $\left.\mathrm{Na}^{+}\right)$and divalent ions $\left(\mathrm{Ca}^{2+}, \mathrm{Mg}^{2+}\right.$ and $\left.\mathrm{SO}_{4}{ }^{2-}\right)$ by the membranes as a function of $\mathrm{pH}$ is displayed in Figure 2

\section{[Figure 2]}

The membranes BW30 and ESPA4 are described by the manufacturers as RO membranes while NF90 and TFC-S are described as NF membranes. The lowest retention was obtained for the TFC-S membrane: $73-81 \%$ for monovalent and $93-98 \%$ for divalent ions (Figure 2D), while the highest retention was achieved using the BW30 membrane: $90-99 \%$ for monovalent and $>99 \%$ for highest retention was achieved using the BW30 membrane: $90-99 \%$ for monovalent and $>99 \%$ for
divalent ions (Figure 2A and E). The ion transport mechanisms in non-porous RO membranes are described by solution-diffusion, while in the looser NF membranes size-exclusion and charge effects play an important role [24-26]. The transition between NF and RO is gradual and ESPA4 and NF90 have very similar retention (Figure 2B and C). Membrane charge is affected by solution $\mathrm{pH}$ [27], where the negative membrane charge and the electrical double layer is reduced at acidic $\mathrm{pH}$, thus allowing easier passage of charged solutes [28]. This effect was observed for the 
monovalent ions $\left(\mathrm{Cl}^{-}, \mathrm{K}^{+}\right.$and $\mathrm{Na}^{+}$), especially for the membranes NF90 and ESPA-4 (Figure 2B and C). As well as lower charge, monovalent ions have a smaller hydrated radius compared to divalent ions, and are therefore less well retained. This effect was less pronounced for the tighter RO membrane (BW30) and also the more open NF membrane TFC-S. Unexpectedly, permeate flux was somewhat higher at $\mathrm{pH}$ 3-4 (Figure S2) for some membranes (ESPA4, NF90 and for BW30 at Pine Hill). The reason for this is difficult to establish due to the complex composition of the rea groundwater sample, but may be due to less fouling at the acidic $\mathrm{pH}$ values when ions are more soluble.

\subsection{Impact of $\mathrm{pH}$ on uranium concentration in the water}

The uranium concentrations decreased after NF/RO filtration from an initial feed concentration of $25 \mu \mathrm{g} / \mathrm{L}$ in Ti Tree Farm and $289-367 \mu \mathrm{g} / \mathrm{L}$ at Pine Hill Station to $<1 \mu \mathrm{g} / \mathrm{L}$ in the permeate solutions for all membranes, except for TFC-S where $7 \mu \mathrm{g} / \mathrm{L}$ were achieved. Those values comply with WHO and ADWG drinking water guidelines.

\section{[Figure 3]}

Results indicated a decrease in retention at $\mathrm{pH}$ 6-7 (Figure S4); this was, however, primarily due to a concentration decrease of uranium in the feed solution. Raff et al. [16] also found decrease in the retention at $\mathrm{pH}$ 5.9; but concentration values were not given. Since the retention decrease does not reflect an increase in permeate concentration, results will be presented as uranium concentrations of the feed, UF permeate, concentrate and NF/RO solutions as a function of $\mathrm{pH}$ (Figure 3). The feed concentration would be expected to remain constant due to the recirculation of permeate and concentrate. However, the uranium concentration decreased in feed, UF permeate and

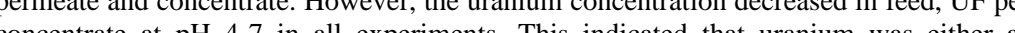

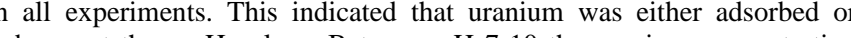
precipitated onto the membrane at these $\mathrm{pH}$ values. Between $\mathrm{pH}$ 7-10 the uranium concentration increased again in the feed, concentrate and UF permeate solutions (except for BW30 at Pine Hil where the concentrations remained low), while at $\mathrm{pH} 10$ and 11 the concentration decreased markedly in these solutions. A similar decrease in solution concentration was observed for some other elements such as manganese, vanadium, nickel, zinc, copper and magnesium at $\mathrm{pH} 10$ [20]. To gain better understanding of the underlying reasons for this behaviour the following section explores the speciation of uranium at different $\mathrm{pH}$.

\subsection{Uranium speciation and precipitation}

The aqueous speciation of uranium under atmospheric pressure can be predicted by inputting elemental concentration data into speciation codes such as Visual Minteq [29-31]. In this study, measured concentrations for a suite of elements [20] provided the basis for the uranium speciation analysis. The results from the speciation calculation for uranium performed using Visua Minteq 5.23 are displayed in Figure 4A and B for Ti Tree Farm and Pine Hill, respectively. The uranium mass adsorbed during the $\mathrm{pH}$ experiments was calculated according to equation 1 . The mass adsorbed, expressed as percentage of the initial feed solution, is given in Figure 4C and D.

$$
\mathrm{M}_{\mathrm{ads}}=\mathrm{V}_{\mathrm{f} 0} \mathrm{C}_{\mathrm{f0}}-\mathrm{V}_{\mathrm{fF}} \mathrm{C}_{\mathrm{fF}}-\mathrm{V}_{\mathrm{p}} \mathrm{C}_{\mathrm{p}}-\mathrm{V}_{\mathrm{c}} \mathrm{C}_{\mathrm{c}}
$$

Where $\mathrm{M}_{\mathrm{ads}}$ is the mass adsorbed $(\mathrm{mg}), \mathrm{V}$ is the volume $(\mathrm{L}), \mathrm{C}$ is the element concentration $(\mathrm{mg} / \mathrm{L})$ and the subscripts $\mathrm{f}, \mathrm{c}$ and $\mathrm{p}$ stand for feed, concentrate and permeate, respectively. Final and initial are indicated by subscripts $F$ and 0 . Note that adsorption on the UF and NF/RO membranes cannot be differentiated in this study.

[Figure 4]
The major species predicted from $\mathrm{pH} 3$ to 11 were $\mathrm{UO}_{2} \mathrm{SO}_{4}, \mathrm{UO}_{2} \mathrm{OH}^{+}, \mathrm{UO}_{2} \mathrm{CO}_{3}$, $\left(\mathrm{UO}_{2}\right)_{2} \mathrm{CO}_{3}(\mathrm{OH})_{3}{ }^{-}, \mathrm{Ca}_{2} \mathrm{UO}_{2}\left(\mathrm{CO}_{3}\right)_{3}$ and $\mathrm{UO}_{2}\left(\mathrm{CO}_{3}\right)_{3}{ }^{4-}$ (Figure $4 \mathrm{~A}$ and B). To evaluate whether this speciation could explain the experimental observations, literature data was used to compare general solubilities and results of other studies. While relatively few experimental data regarding the solubility products of the above listed species have been published and are hard to determine [32], especially as the solubility is highly influenced by any other ions present in the solution, comparion of $\log \mathrm{K}$ values (stability conts) could be me $[3,22,29]$. The species, comparis as of log $K$ values (stakity con are remaining in solution rather than on the membrane:

\section{$\mathrm{UO}_{2} \mathrm{OH}^{+}<\left(\mathrm{UO}_{2}\right)_{2} \mathrm{CO}_{3}(\mathrm{OH})_{3}{ }^{-}<\mathrm{UO}_{2} \mathrm{SO}_{4}<\mathrm{UO}_{2} \mathrm{CO}_{3}<\mathrm{UO}_{2}\left(\mathrm{CO}_{3}\right)_{3}{ }^{4-}<\mathrm{Ca}_{2} \mathrm{UO}_{2}\left(\mathrm{CO}_{3}\right)_{3}$}

At the most acidic $\mathrm{pH}$, uranyl sulphate was predominant at both sites. In the Ti Tree Farm water it constituted about $45 \%$ and in the Pine Hill water it was about $78 \%$ of the total uranium species. Several other studies have similarly found $\mathrm{UO}_{2} \mathrm{SO}_{4}$ as the dominant species at low $\mathrm{pH}$ in waters with high sulphate content $[33,34]$. Uranyl sulphate complexes are relatively soluble, which was reflected in a low mass of uranium adsorbed at $\mathrm{pH} 3$ (Figure 4C and D).

At $\mathrm{pH} 4.5$, the proportion of the uranyl sulphate ion and of the uranyl ion decreased while that of $\mathrm{UO}_{2} \mathrm{OH}^{+}$increased. The latter was predominant between $\mathrm{pH} 5.5$ and 6.5. This falls within the $\mathrm{pH}$ range where the first concentration decrease occurred, indicating membrane deposit formation. At $\mathrm{pH} 5$, the mass of uranium adsorbed varied amongst the membrane types from $45 \%$ deposition for TFC-S to $82 \%$ deposition for the RO membrane BW30. For all membranes, the mass adsorbed increased to $90 \%-99 \%$ at $\mathrm{pH}$ 6. A variety of other studies have shown that uranium is easily adsorbed onto different materials or immobilised at $\mathrm{pH} 5-6[33,35]$ and also implicated $\mathrm{UO}_{2} \mathrm{OH}^{+}$in the these processes [36]. The adsorption may be due to charge interactions, as the (37], which would attract the positive uranium species. Precipitation maxima for solutions containing uranium at similar concentrations to the tested Pine Hill water have been observed at $\mathrm{pH} 6$ [38], the same $\mathrm{pH}$ at which the maximum deposition occurred on the membranes. Similarly, Semião et al. [15] demonstrated that uranium is deposited onto UF membranes at $\mathrm{pH} 5-6$, which indicates that the uranium not only deposited onto the NF/RO membranes but also the UF membranes.

At $\mathrm{pH}$ 8-9.5, $\mathrm{Ca}_{2} \mathrm{UO}_{2}\left(\mathrm{CO}_{3}\right)_{3}$ was the dominant uranium speciation predicted. At this poin uranium was again detected in the feed, UF permeate and concentrate solutions, although not to the ame extent as in the original solution. The mass adsorbed was calculated to be between 54-68\% for uranium speciation has been found by other investigators [39] and uranium is often found in association with calcium in natural waters [40]. In addition, dissolved calcium and magnesium species have been found to decrease uranium adsorption to minerals at neutral-alkaline $\mathrm{pH}$ [41] Winde et al. [34] attributed the mobility of uranium in sediments to the presence of negatively charged or neutral calcium uranium carbonate complexes which do not adsorb onto negatively charged sediment surfaces. In this study, it is proposed that as $\mathrm{Ca}_{2} \mathrm{UO}_{2}\left(\mathrm{CO}_{3}\right)_{3}$ is a neutral species, it would not be electrostatically attracted to a negative membrane and this results in the observed lower adsorbed mass.

At $\mathrm{pH} 10$, uranium was not detected in the solutions, and the mass balance showed that 95 $100 \%$ of the uranium was deposited on all membranes (Figure $4 \mathrm{C}$ and $\mathrm{D}$ ). At this $\mathrm{pH}$ the highly soluble $\mathrm{UO}_{2}\left(\mathrm{CO}_{3}\right)_{3}{ }^{4-}$ complex was predicted to dominate (Figure 4A and B) [3]. At such a high pH, the membranes are negatively charged, so electrostatic attraction to the membrane cannot explain the deposition. It has been found that that $\mathrm{UO}_{2}\left(\mathrm{CO}_{3}\right)_{3}{ }^{4-}$ adsorbed to hydrous ferric oxide at high $\mathrm{pH}$ and oxic conditions [42]. In this study however, less than $0.2 \mathrm{mg} / \mathrm{L}$ of iron $(\mathrm{Fe})$ was present in Pine Hill and Ti Tree waters, and so it is necessary to look at possible interactions with other elements. High levels of calcium and magnesium (up to 60 and $150 \mathrm{mg} / \mathrm{L}$ ) were found, and magnesium did show similar removal from solution at $\mathrm{pH} 10$ in the experiments. Indeed calcium and magnesium 
complexes have been found to effectively remove uranium from solution at $\mathrm{pH}>10[12,33]$. From the predictive speciation for these two cations in Ti Tree Farm and Pine Hill Station water, $\mathrm{CaCO}$ (calcite) and $\mathrm{MgCO}_{3}$ (magnesite) formed at $\mathrm{pH} 10$, whilst at lower $\mathrm{pH}$, the free ions (soluble) dominated (Figure 4E and $\mathrm{F}$ ). $\mathrm{CaCO}_{3}$ and $\mathrm{MgCO}_{3}$ have very low solubility $\left(\mathrm{K}_{\mathrm{sp}}=3.36 \times 10^{-9}\right.$ and $6.82 \times 10^{-6}$ respectively) and calcite is well known to cause membrane scaling [43]. Calcium and magnesium were present at very high concentrations relative to uranium, and $\mathrm{UO}_{2}\left(\mathrm{CO}_{3}\right)_{3}{ }^{4-}$ is likely to co-precipitate as they reach their solubility limits. In fact, many of the minerals predicted using to co-precipitate as his pentar those containing calcium, magnesium, copper, vanadium and iron. The significance of the calcium and magnesium is likely to be greater in this study, as copper, vanadium and iron were only present at very low concentrations (all $<0.22 \mathrm{mg} / \mathrm{L}$ in Pine Hill compared to 60 and $150 \mathrm{mg} / \mathrm{L}$ for calcium and magnesium). Uranium has been found by other studies to co-precipitate with calcite $[44,45]$. A study investigating the use of electrodialysis (ED) to purify the Pine Hill water was performed by Banasiak and Schäfer [46] and similarly found that scaling by calcium, magnesium, potassium and chloride ions occurred on the ED membrane.

To give an indication of membrane performance depending on feed water quality and operating parameters, RoPro 7.0 was used to evaluate the data for the Ti Tree Farm and Pine Hill groundwater and the TFC-S membrane. The model predicted that for example $\mathrm{BaSO}_{4}$ would reach saturation in the concentrate stream of both Pine Hill and Ti Tree Farm (SI of 2.14 and 1.80 , respectively) at the natural $\mathrm{pH}$ of the water (8.4). While RoPro is a helpful tool in predicting precipitation of simple minerals, the experimental results indicate that co-precipitates involving uranium, are not taken into account by the programme, and may also affect membrane performance.

The chemical speciation software Minteq, only calculates the saturation of a compound based on the feed water concentration, while RoPro takes into account the increased concentration taking place as a result of the membrane process. Thus, Minteq did not predict $\mathrm{BaSO}_{4}$ to reach tatur reach saturation $(\mathrm{SI}=1.54)$ at a concentration 10 times the original solution independently of $\mathrm{pH}$ This is a similar SI to that predicted for $\mathrm{BaSO}_{4}$ by RoPro and reflects the increased concentration at the membrane surface due to concentration polarization. This illustrates the potential of coupling chemical speciation modelling and process simulation tools.

\subsection{Uranium retention and specific energy consumption with solar energy}

Two experiments to test the impact of using solar energy and the subsequent natural energy variation were performed. In the solar batch experiment, permeate and concentrate solutions were re-circulated back into the feed tank, while in the solar continuous experiment, the feed tank was continuously filled from the borehole while permeate and concentrate solutions were collected in separate containers. This resulted in a constant flow of inorganic contaminants into the system.

$$
\text { [Figure 5] }
$$

The retention of major cations during the batch experiment at Pine Hill was high, $>99 \%$ for major divalent cations (calcium and magnesium), including uranium, and $95-98 \%$ for monovalent cations (e.g. potassium and sodium) throughout the experiment. During the continuous experiment, the retention of major cations was also high: $94-99 \%$ for divalent cations and $87-98 \%$ for monovalent cations. Discussion on the retention of the different ions, is found in Richards et al. [20]. The amount of uranium in the concentrate decreased over the course of both experiments to about a third of the original value, indicating deposition of uranium on the membrane. There was also a higher uranium concentration in the permeate solution at the end of the experiment, indicating that uranium may be accumulating on the membrane and eventually permeating. As a consequence, during the continuous experiment, permeate samples with concentrations as high as $67 \mu \mathrm{g} / \mathrm{L}$ were measured, which exceeds the WHO drinking water guideline of $15 \mu \mathrm{g} / \mathrm{L}$. Further fundamental bench-scale studies are in progress to elucidate the mechanistic reasons for these observations

The specific energy consumption (SEC) gives a measure of how much energy is needed for the pump to produce the permeate and was calculated from equation 2 [18]. The less energy required, the more efficient the system.

$$
\mathrm{S} E C=\frac{\mathrm{I}_{\text {pump }} \mathrm{U}_{\text {pump }}}{\mathrm{Q}_{\text {permeate }}}
$$

Where $\mathrm{I}$ is the current $(\mathrm{A}), \mathrm{U}$ is the voltage $(\mathrm{V})$-both of the pump- and $\mathrm{Q}$ is permeate flow $(\mathrm{L} / \mathrm{h})$ The SEC depends on permeate flow, feed flow (which affects the energy requirements) pressure and the salinity of the water (which affects the osmotic pressure) [18]. The SEC continuously increased over the course of the experiment (Figure 5). While pressure and feed flow were relatively constant, the permeate flow decreased towards the end of the experiment (results not shown). This indicates that the SEC increase was due to fouling of the membrane, as energy demand increased and permeate flow declined [19]. To determine the amounts of inorganic elements deposited for the batch and continuous experiments, the mass adsorbed to the membrane during the batch experiment was calculated using equation 1 . The mass adsorbed during the continuous experiment was calculated according to equation 3 , as the sum of each sample set.

$$
\mathrm{M}_{\mathrm{ads}}=\sum_{\mathrm{i}=1}^{11} t_{i}\left(Q_{f} \cdot c_{f}-Q_{c} \cdot c_{c}-Q_{p} \cdot c_{p}\right)
$$

Where, $t$ is each time step (1-11) that was sampled (h), $\mathrm{Q}$ is flow $(\mathrm{L} / \mathrm{h}), \mathrm{C}$ is the concentration of an element $(\mathrm{mg} / \mathrm{L})$, and subscripts as for equation 1 .

The mass balance for calcium in the batch experiment showed that a large portion $(88 \%)$ of calcium had precipitated on the membrane by the end of the experiment, a probable cause of the observed SEC increase. About $2.8 \mathrm{mg}(4 \%)$ of the uranium originally present in the feed solution adsorbed. The mass balance for the continuous experiment for uranium showed that the adsorption was higher at about $335 \mathrm{mg}$ or $17 \%$ of the total uranium in the feed solution. The permeate concentration of uranium was also high (up to $67 \mu \mathrm{g} / \mathrm{L}$ ) in the continuous experiment, indicating that any uranum which had sorbed to or precipitated on the membrane was possibly diffusing embrane or being displaced by other ions. The uranium retention decreased over the course of the experiment from $98 \%$ to $84 \%$. Concentration polarisation may enhance this effect [24] due to a concentration gradient at the membrane surface, causing diffusion of ions to the dilute permeate side. The $\mathrm{pH}$ values of the feed water during the batch and continuous experiments were 8.3-8.6 and 7.7-8.2 respectively. The main uranium species at $\mathrm{pH}$ 7.7-8.6 was predicted as $\mathrm{Ca}_{2} \mathrm{UO}_{2}\left(\mathrm{CO}_{3}\right)_{3}$ (Figure 4B), out of which around $60 \%$ adsorbed to the membranes during the $\mathrm{pH}$ experiments. The permeate $\mathrm{pH}$ values of the batch and continuous experiments were 6.3-7.9 and 5.9-6.1, respectively. At those $\mathrm{pH}$ values, the uranium species would be a mixture of (heriments over $90 \%$ of the uranium adsorbed to the

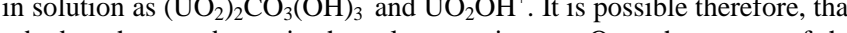
uranium also becme ad experiment some uranium could diffuse through the fouled membrane, leading to the consequent break-through on the permeate side.

\section{Conclusions}

The solution chemistry is bound to be complex when treating real brackish groundwater with ion selective membranes. While uranium was removed by this solar powered membrane filtration system, membrane sorption and permeation occurred at certain conditions. The speciation of uranium using Visual Minteq was useful in explaining the adsorption to the membrane that 
occurred at $\mathrm{pH}$ 5-7. Uranium removal from solution by co-precipitation with calcium was also consistent with the speciation prediction of calcium and magnesium precipitation at $\mathrm{pH} 10$. Adsorption and co-precipitation are important considerations in membrane processes when the removal of a complex mixture of inorganic elements is performed, as well as when $\mathrm{pH}$ adjustment is employed, e.g. in scaling control. The system performed well also when operating on solar energy, importantly however, it was found that there was breakthrough of uranium to the permeate solution due to scaling, which requires further investigation of less complex solutions.

\section{Acknowledgements}

The project is funded through the Australian Research Council Linkage Project LP0349322 in collaboration with Mono Pumps Australia while a 2005 Mondialogo Award (UNESCO/DaimlerChrysler Partnership) has funded the project implementation stage through the field trial. John Childs (Northern Territory Power and Water; CRC Desert Knowledge) is acknowledged for his support with bore water quality data and desert logistics for the field trial. The authors would like to thank Gil Bowman (Pine Hill Station) for his hospitality and insightful discussions, as well as the field trial sponsors BP Solar (Australia), GHD Pty. Ltd. (Water Group, Brisbane), Department of Environment and Heritage, New South Wales Department of Commerce, and the Australian National University. A very special thank you goes to the students who participated in the field trial; Kai Ratte, Melanie Werner, Thomas Kruttschnitt and Philipp Sausele. In addition we would like to thank Dr Tim Payne and Mr Henri Wong at ANSTO, Australia for partial sample analysis and some speciation discussions. Dr Lorna Eades is thanked for assistance of some sample analysis using ICP-MS. Prof Menachem Elimelech is thanked for his constructive comments on the manuscript as a RAEng distinguished visiting fellow. An EPSRC-ESRC studentship for Helfrid Rossiter is appreciated.

\section{Supporting Information}

The supporting information contains more details on the membranes used (Table S1), the experimental conditions for both $\mathrm{pH}$ and solar experiments (Figures S1 and S3), permeate flux for $\mathrm{pH}$ experiments (Figure S2) as well as graphs of uranium retention (Figure S4).

\section{References}

[1] K.B. Pelig-Ba, Trace elements in groundwater from some crystalline rocks in the Upper Regions of Ghana, Water Air Soil Pollut. 103 (1998) 71.

[2] M. Bissen, F.H. Frimmel, Arsenic - a review. - Part 1: Occurrence, toxicity, speciation, mobility, Acta Hydroch. Hydrob. 31 (2003) 9. [3] D. Langmuir, Aqueous Environmental Geochemistry, Prentice Hall, Upper Saddle River, 1997.

[4] B.F. Myasoedov, A.P. Novikov, Main sources of radioactive contamination in Russia and methods for their determination and speciation, J. Radioanal. Nucl. Chem. 229 (1998) 33.

[5] I.W. Oliver, M.C. Graham, A.B. MacKenzie, R.M. Ellam, J.G. Farmer, Distribution and partitioning of depleted uranium (DU) in soils at weapons test ranges - Investigations combining the BCR extraction scheme and isotopic analysis, Chemosphere. 72 (2008) 932.

[6] P. Kurttio, H. Komulainen, A. Leino, L. Salonen, A. Auvinen, H. Saha, Bone as a possible target of chemical toxicity of natural uranium in drinking water, Environ. Health Perspect. 113 (2005) 68.

[7] A.C. Miller, K. Brooks, J. Smith, N. Page, Effect of the militarily-relevant heavy metals, depleted uranium and heavy metal tungsten-alloy on gene expression in human liver carcinoma cells (HepG2), Mol. Cell. Biochem. 255 (2004) 247.

[8] The Royal Society, The health effects of depleted uranium munitions: a summary, J. Radiol. Prot. 22 (2002) 131.

[9] B.J. Alloway, D.C. Ayres, Chemical principles of environmental pollution, Blackie Academic \& Professional, Glasgow, 1993.
[10] World Health Organisation, Guidelines for drinking water quality: first addendum to third edition, Volume 1: Recommendations, Geneva, 2006, p. 515.

[11] P. Huikuri, L. Salonen, O. Raff, Removal of natural radionuclides from drinking water by point of entry reverse osmosis, Desalination. 119 (1998) 235.

[12] S. Chellam, D.A. Clifford, Physical-chemical treatment of groundwater contaminated by leachate from surface disposal of uranium tailings, J. Environ. Eng. 128 (2002) 942.

[13] E.W. Tiepel, Application of advanced membrane filtration to industrial wastewater treatment and groundwater clean-up, The International Water Conference 46th Annual
Meeting, Engineers Society of Western Pennsylvania Pittsburgh, PA, USA, 1985, pp. 35-43.

[14] A. Favre-Reguillon, G. Lebuzit, J. Foos, A. Guy, A. Sorin, M. Lemaire, M. Draye, Selective rejection of dissolved uranium carbonate from seawater using cross-flow filtration technology, Sep. Sci. Technol. 40 (2005) 623.

[15] A.C. Semião, H.M.A. Rossiter, A.I. Schäfer, Impact of organic matter and speciation on the behaviour of uranium in submerged ultrafiltration, J. Membr. Sci.(accepted).

[16] O. Raff, R.D. Wilken, Removal of dissolved uranium by nanofiltration, Desalination. 122 (1999) 147.

[17] A. Favre-Reguillon, G. Lebuzit, D. Murat, J. Foos, C. Mansour, M. Draye, Selective removal of dissolved uranium in drinking water by nanofiltration, Water Res. 42 (2008) 1160 .

[18] A.I. Schäfer, A. Broeckmann, B.S. Richards, Renewable energy powered membrane technology 1. development and characterisation of a photovoltaic hybrid membrane system, Env. Sci. Technol. 41 (2007) 998

[19] B.S. Richards, D.P.S. Capão, A.I. Schäfer, Renewable energy powered membrane technology. 2. The effect of energy fluctuations on performance of a photovoltaic hybrid membrane system, Environ. Sci. Technol. 42 (2008) 4563.

[20] L.A. Richards, B.S. Richards, A.I. Schäfer, Renewable energy powered membrane technology. 3. Trace contaminant removal by nanofiltration/reverse osmosis, Env. Sci. Technol.(in preparation).

[21] J.D. Allison, D.S. Brown, K.J. Novo-Gradac, MinteqA2 / ProdefA2, A geochemical assessment model for environmental systems, US Environmental Protection Agency, Athens, GA, USA, 1991.

[22] I. Grenthe, J. Fuger, R.J.M. Konings, R. Lemire, J., A.B. Muller, C. Nguyen-Trung Cregu, $\mathrm{H}$. Wanner, Chemical thermodynamics of uranium, in: H. Wanner, I. Forest, (Eds), OECD Nuclear Energy Agency, Paris, 1992.

[23] R. Guillaumont, T. Fanghanel, J. Fuger, Update on the chemical thermodynamics of uranium, neptunium, plutonium, americium and technetium, OECD, 2003.

[24] A.I. Schäfer, A.G. Fane, T.D. Waite, Nanofiltration - Principles and Applications, Elsevier, 2005.

[25] J.G. Wijmans, R.W. Baker, The solution-diffusion model - a review, J. Membr. Sci. 107 (1995) 1 .

[26] B. Van der Bruggen, C. Vandecasteele, Removal of pollutants from surface water and groundwater by nanofiltration: overview of possible applications in the drinking water industry, Environ. Pollut. 122 (2003) 435

[27] A.E. Childress, M. Elimelech, Effect of solution chemistry on the surface charge of polymeric reverse osmosis and nanofiltration membranes J. Membr. Sci. 119 (1996) 253.

[28] A. Braghetta, F.A. DiGiano, W.P. Ball, Nanofiltration of natural organic matter: $\mathrm{pH}$ and ionic strength effects, J. Environ. Eng. 123 (1997) 628.

[29] T.E. Payne, Uranium (VI) interactions with mineral surfaces: controlling factors and surface complexation modelling, PhD, University of New South Wales, 1999.

[30] C. Kantar, Heterogeneous processes affecting metal ion transport in the presence of organic ligands: Reactive transport modeling, Earth Sci. Rev. 81 (2007) 175. 


\section{Rossiter, H. ; Graham, M. J. ; Schäfer, A.I. ; (2010) Impact of speciation on behaviour of uranium in a solar powered membrane system for treatment of brackish groundwater,}

Journal of Separation and Purification Technology, 71, 89-96.

doi:10.1016/j.seppur.2009.11.006

[31] J.J. Zhao, Fasfous, II, J.D. Murimboh, T. Yapici, P. Chakraborty, S. Boca, C.L. Chakrabarti, Kinetic study of uranium speciation in model solutions and in natural waters using Competitive Ligand Exchange Method, Talanta. 77 (2009) 1015.

[32] D. Gorman-Lewis, P.C. Burns, J.B. Fein, Review of uranyl mineral solubility measurements, J. Chem. Thermodyn. 40 (2008) 335.

[33] A. Baeza, M. Fernandez, M. Herranz, F. Legarda, C. Miro, A. Salas, Removing uranium and radium from a natural water, Water Air Soil Pollut. 173 (2006) 57.

[34] F. Winde, I.J. van der Walt, The significance of groundwater-stream interactions and fluctuating stream chemistry on waterborne uranium contamination of streams - a case study from a gold mining site in South Africa, J. Hydrol. 287 (2004) 178.

[35] R.T. Pabalan, D.R. Turner, Uranium(6+) sorption on montmorillonite: experimental and surface complexation modeling study, Aquat. Geochem. 2 (1997) 203.

[36] M. Sutton, P. Warwick, A. Hall, Uranium(VI) interactions with OPC/PFA grout, J. Environ. Monit. 5 (2003) 922

[37] C.Y.Y. Tang, Y.N. Kwon, J.O. Leckie, Characterization of humic acid fouled reverse osmosis and nanofiltration membranes by transmission electron microscopy and streaming potential measurements, Env. Sci. Technol. 41 (2007) 942.

[38] E. Matijević, N. Pavković, On precipitation and coagulation effects of uranyl phosphates and sodium uranates, Kolloid-Z. 159 (1958) 1.

[39] S. Tsushima, Y. Uchida, T. Reich, A theoretical study on the structures of UO2(CO3)(3)(4 ), Ca2UO2(CO3)(3)(0), and Ba2UO2(CO3)(3)(0), Chem. Phys. Lett. 357 (2002) 73.

[40] M.P. Elless, S.Y. Lee, Uranium solubility of carbonate-rich uranium-contaminated soils, Water Air Soil Pollut. 107 (1998) 147.

[41] P.M. Fox, J.A. Davis, J.M. Zachara, The effect of calcium on aqueous uranium(VI) speciation and adsorption to ferrihydrite and quartz, Geochim. Cosmochim. Acta. 70 (2006) 1379 .

[42] A.M. Giblin, B.D. Batts, D.J. Swaine, Laboratory simulation studies of uranium mobility in natural waters, Geochim. Cosmochim. Acta. 45 (1981) 699.

[43] A.I. Schäfer, A.G. Fane, T.D. Waite, Nanofiltration of natural organic matter: Removal, fouling and the influence of multivalent ions, Desalination. 118 (1998) 109

[44] J.G. Catalano, J.P. McKinley, J.M. Zachara, S.M. Heald, S.C. Smith, G.E. Brown, Change in uranium speciation through a depth sequence of contaminated Hanford sediments, Env. Sci. Technol. 40 (2006) 2517.

[45] J. Suksi, T. Ruskeeniemi, L. Saarinen, Selective extractions in uranium migration studies Findings from a natural analogue study at Palmottu, southern Finland, J. Contam. Hydrol. 21 (1996) 47

[46] L.J. Banasiak, A.I. Schäfer, Removal of inorganic trace contaminants by electrodialysis in a remote Australian community, Desalination. 248 (2009) 48

\section{List of Figure}

Figure 1 Schematic diagram describing the flow in the membrane system. Large dotted lines represent continuous operation, while solid lines represent batch operation where water was recirculated to the feed tank. The schematic shows UF membranes submerged in the feed tank; a positive displacement pump; NF/RO membrane; $\mathrm{P}$ = pressure gauges; $\mathrm{P1}-3$ = pressure transducers; F1-2 = flow sensors; V1 = pressure relief valve; V2 = press guided by global positioning system and MPPT = maximum powe experiments, the pump operated under constant energy supply and the water was re-circulated to the feed tank. During solar experiments the pump was connected to a PV array. During solar batch the water was re-circulated, while in the solar continuous experiment, the water not re-circulated but the feed tank continuously re-filled from the source.

Figure 2 Retention of important salt ions for A) BW30 (Ti Tree Farm), B) NF90, C) ESPA4 D) TFC-S and E) BW30 (all Pine Hill). Full symbols are divalent ions $\left(\mathrm{SO}_{4}{ }^{2-}, \mathrm{Ca}^{2+}\right.$ and $\mathrm{Mg}^{2+}$ while open symbols are monovalent ions $\left(\mathrm{Na}^{+}, \mathrm{K}^{+}\right.$and $\left.\mathrm{Cl}^{-}\right)$.

Figure 3 Uranium concentration as a function of $\mathrm{pH}$ in feed, UF permeate, NF/RO permeate and concentrate using four different membranes A) BW30 (Ti Tree Farm), B) NF90, C) ESPA4, D TFC-S and E) BW30 (all Pine Hill). Note the different scale for Ti Tree Farm due to lower uranium concentration.

Figure 4 Uranium, magnesium and calcium species predicted using Visual Minteq 2.53 in Ti Tree Farm $(A, E)$ and Pine Hill waters (B, F). Uranium mass adsorbed is displayed in graph $C$ and $D$.

Figure 5 Uranium concentration, specific energy consumption (SEC) and solar radiation for solar batch (A) and continuous (B) experiments at Pine Hill with BW30 over the course of a day. 
Rossiter, H. ; Graham, M. J. ; Schäfer, A.I. ; (2010) Impact of speciation on behaviour of uranium in a solar powered membrane system for treatment of brackish groundwater, Journal of Separation and Purification Technology, 71, 89-96.

doi:10.1016/j.seppur.2009.11.006

Figure 1

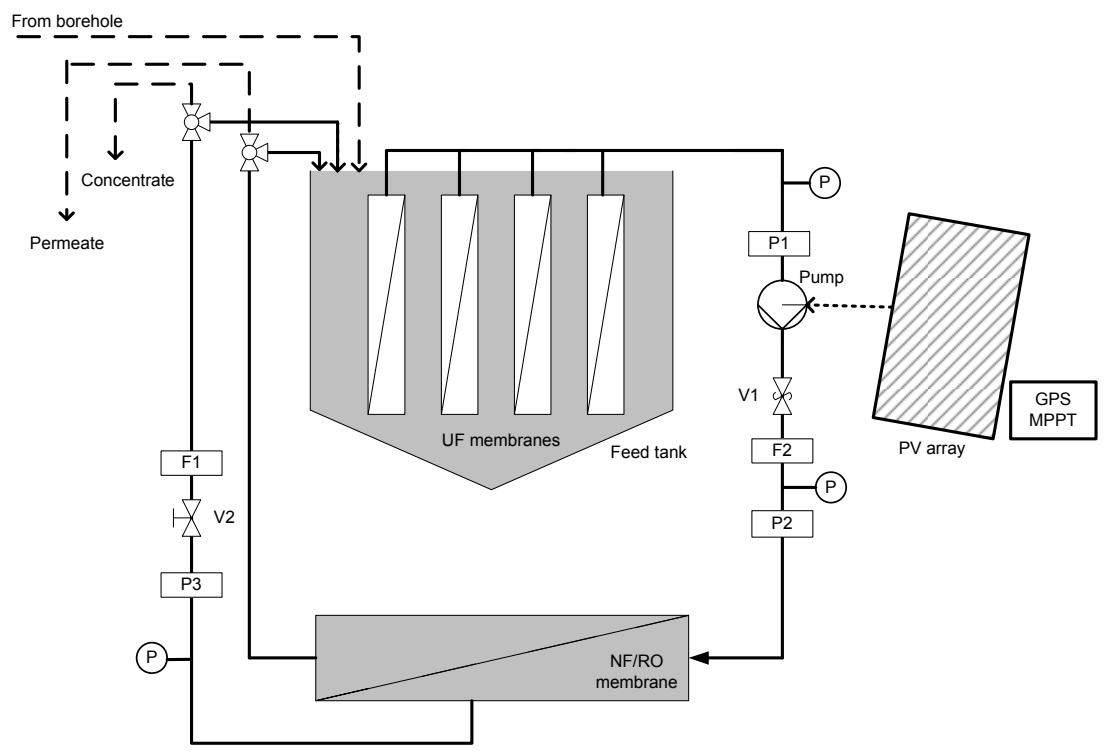

Figure 2

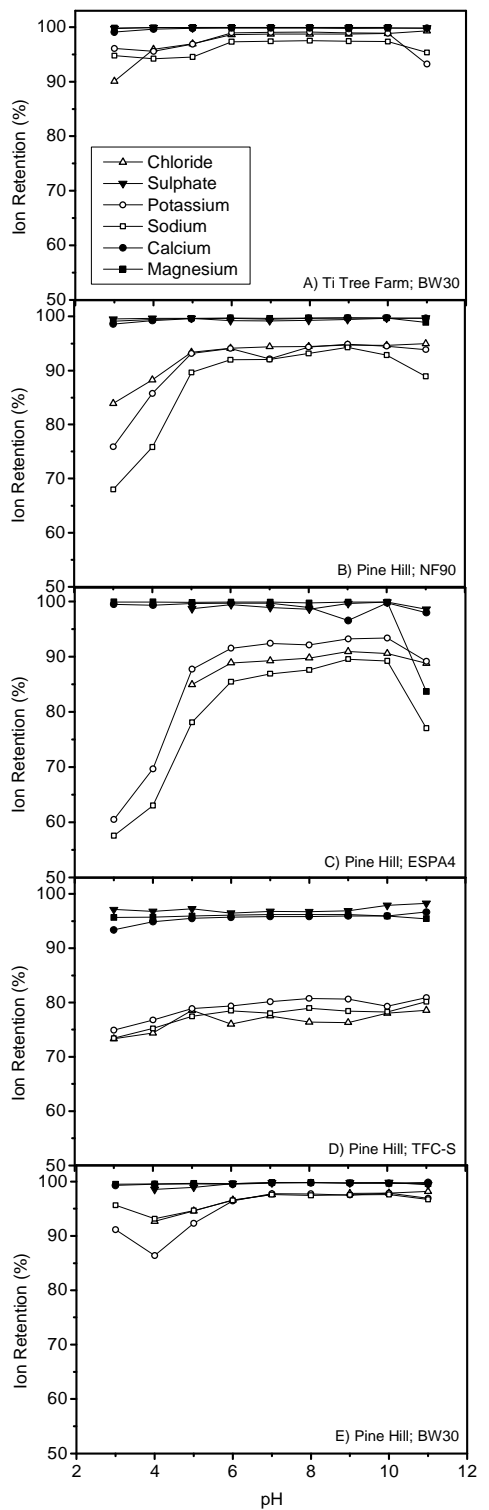


Rossiter, H. ; Graham, M. J. ; Schäfer, A.I. ; (2010) Impact of speciation on behaviour of uranium in a solar powered membrane system for treatment of brackish groundwater, Journal of Separation and Purification Technology, 71, 89-96.

doi:10.1016/j.seppur.2009.11.006

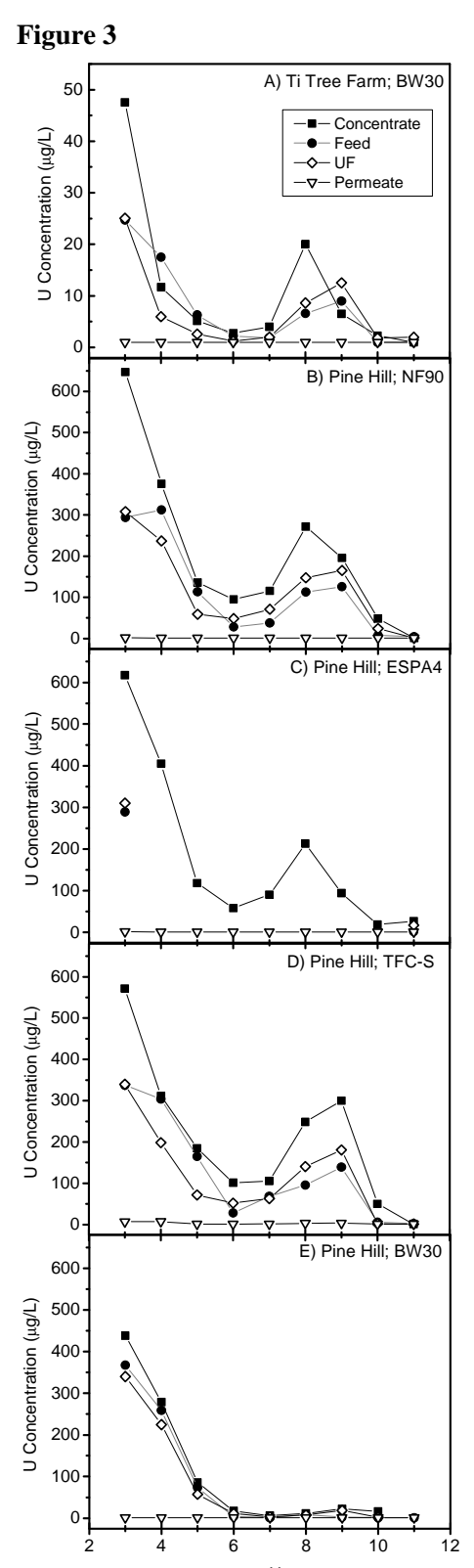

Figure 4
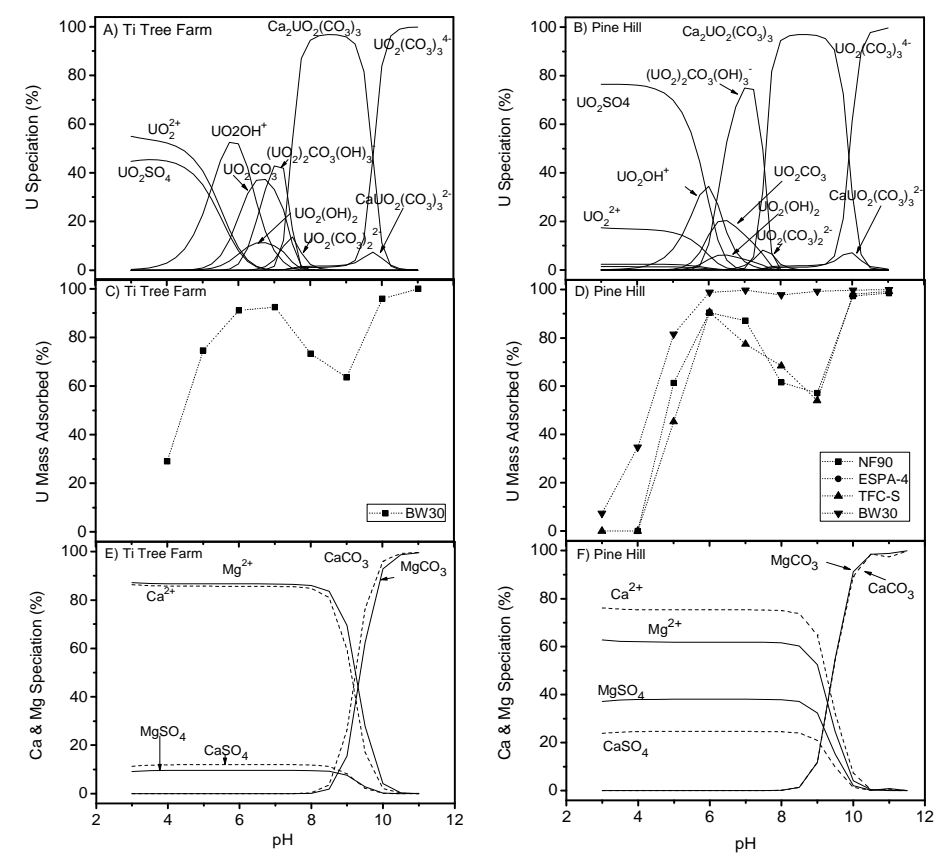
Rossiter, H. ; Graham, M. J. ; Schäfer, A.I. ; (2010) Impact of speciation on behaviour of uranium in a solar powered membrane system for treatment of brackish groundwater, Journal of Separation and Purification Technology, 71, 89-96.

doi:10.1016/ן.seppur.2009.11.006

\section{Figure 5}

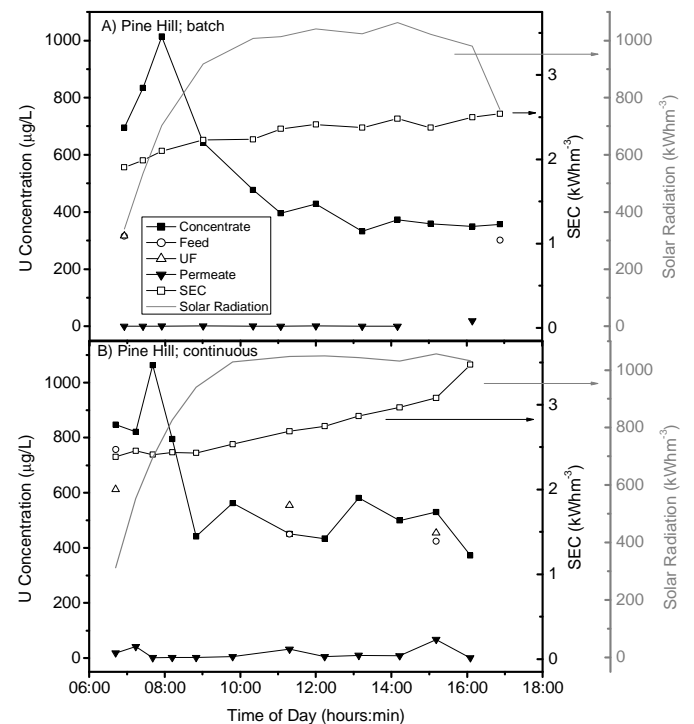

\section{Supporting Information} for treatment of brackish groundwater

Helfrid M.A. Rossiter, Margaret C. Graham and Andrea I. Schäfer

*Corresponding author e-mail: Andrea.Schaefer@ed.ac.uk

\section{SI 1 Membrane characteristics}

An overview of typical retention values as well as membrane materials according to membrane manufacturers is given in Table S1.

Table S1. Overview of membrane type, typical retention and test conditions according to manufacturer product information (TFC: thin film composite; PA: polyamide; PS: polysulfone).

\begin{tabular}{|c|c|c|c|c|c|c|c|}
\hline Membrane & Ref & Type & $\begin{array}{c}\mathrm{NaCl} \\
\text { retention }\end{array}$ & $\begin{array}{c}\mathrm{MgSO}_{4} \\
\text { retention }\end{array}$ & Material* & Supplier & $\begin{array}{c}\text { Test } \\
\text { conditions }\end{array}$ \\
\hline NF90 & [1] & $\mathrm{NF}$ & - & $55 \%$ & PA TFC & Filmtech & $\begin{array}{c}2000 \mathrm{mg} / \mathrm{L} \\
\mathrm{MgSO}_{4}, 4.8 \\
\text { bar, } 25^{\circ} \mathrm{C}, 15 \% \\
\text { recovery }\end{array}$ \\
\hline TFC-S & [2] & NF & $>80 \%$ & $99 \%$ & $\begin{array}{l}\text { PA TFC } \\
\text { with PS } \\
\text { support }\end{array}$ & $\begin{array}{c}\text { Koch } \\
\text { Membrane } \\
\text { Systems }\end{array}$ & $\begin{array}{c}1000 \mathrm{mg} / \mathrm{L} \\
\mathrm{MgSO}_{4}, 5.5 \\
\mathrm{bar}, 25^{\circ} \mathrm{C}, \mathrm{pH} \\
7.515 \% \\
\text { recovery }\end{array}$ \\
\hline ESPA4 & {$[3]$} & RO & 99.2 & - & $\begin{array}{c}\text { Composite } \\
\text { PA }\end{array}$ & Hydranautics & $\begin{array}{c}500 \mathrm{mg} / \mathrm{L} \\
\mathrm{NaCl}, 6.9 \text { bar, } \\
25^{\circ} \mathrm{C}, \\
\mathrm{pH} 6.5-7.0 \\
15 \% \text { recovery }\end{array}$ \\
\hline BW30 & [4] & RO & $>99.5 \%$ & - & PA TFC & Filmtec & $\begin{array}{c}2000 \mathrm{mg} / \mathrm{L} \\
\mathrm{NaCl}, 15.5 \mathrm{bar} \\
25^{\circ} \mathrm{C}, 15 \% \\
\text { recovery }\end{array}$ \\
\hline
\end{tabular}

SI 2 Experimental conditions for $\mathrm{pH}$ experiments

The average temperatures were $31.27 \pm 1.03^{\circ} \mathrm{C}, 24.90 \pm 0.30{ }^{\circ} \mathrm{C}, 28.16 \pm 0.7^{\circ} \mathrm{C}, 25.74 \pm 0.9^{\circ} \mathrm{C}$ and $24.73 \pm 2.4^{\circ} \mathrm{C}$ for the experiments with BW30 at Ti Tree and NF90, ESPA4, TFC-S and BW30 at Pine Hill, respectively. See graphs below for overview of the temperature and feed flow variation throughout the experiment. It can be concluded that both flow and temperature were fairly constant through-out the individual experiments, except for BW30 in Pine Hill, where the temperature decreased by about $2.5^{\circ} \mathrm{C}$. 
Rossiter, H. ; Graham, M. J. ; Schäfer, A.I. ; (2010) Impact of speciation on behaviour of uranium in a solar powered membrane system for treatment of brackish groundwater, Journal of Separation and Purification Technology, 71, 89-96.

doi:10.1016/ן.seppur.2009.11.006

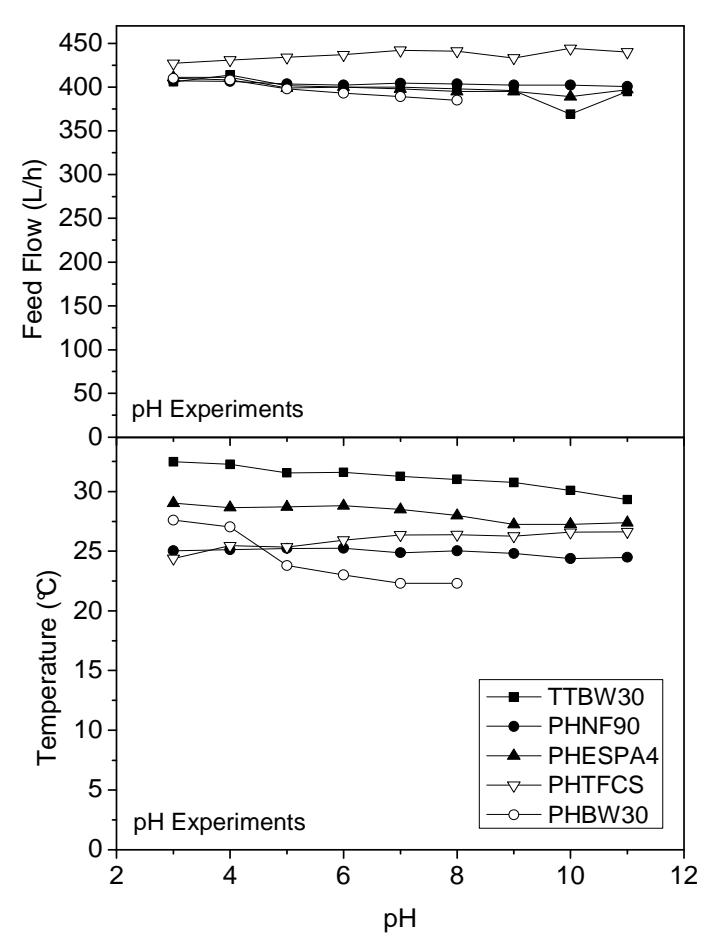

pressure dropped to 8-9 bar for the solar batch experiment. The feed flow was about $400 \mathrm{~L} / \mathrm{h}$. The temperature increased from 25 to about $32^{\circ} \mathrm{C}$ for the solar batch experiment while for the solar continuous experiment the temperature increased from 19 to $30^{\circ} \mathrm{C}$

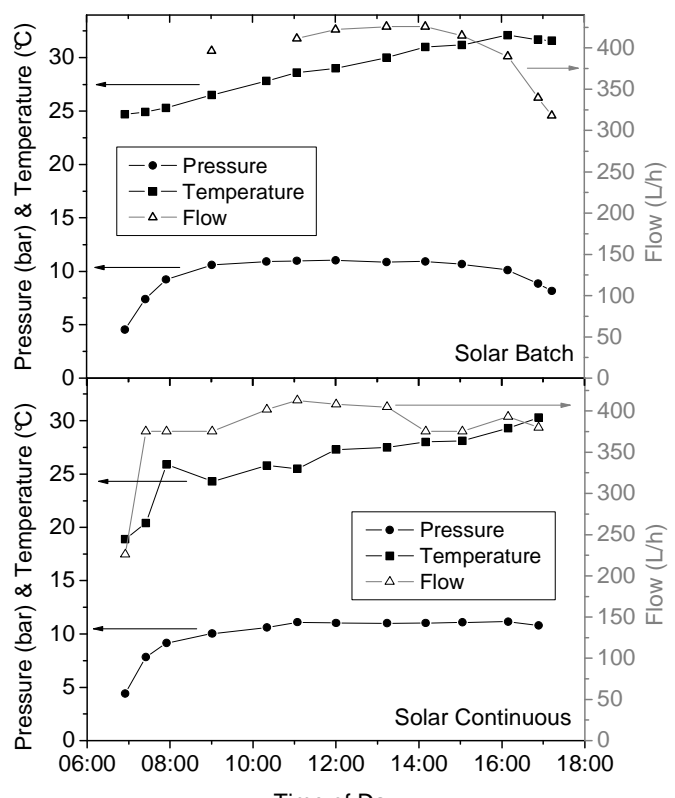

Figure S3 Pressure, temperature and feed flow $(\mathrm{L} / \mathrm{h})$ over the course of the solar day for the Station).

Figure S1 Feed flow and temperature as a function of $\mathrm{pH}$ (TT: Ti Tree Farm, PH: Pine Hill

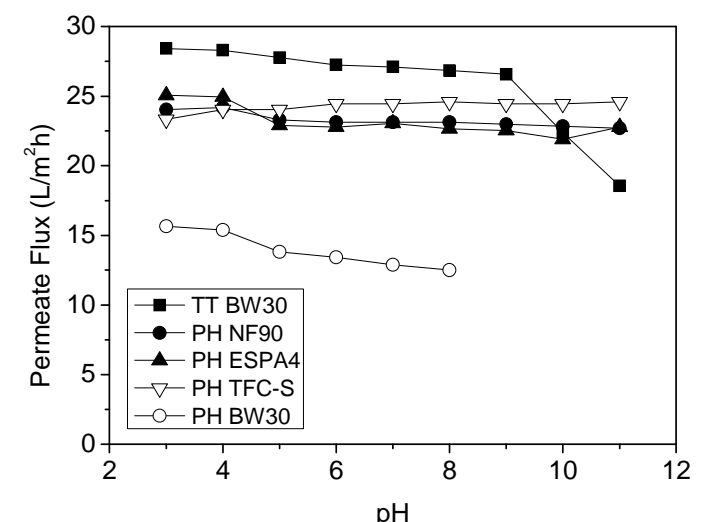

Figure S2 Permeate flux as a function of pH (TT: Ti Tree Farm, PH: Pine Hill Station).

SI 3 Experimental conditions for solar experiments

The Pressure increased with solar radiance from 4 bar at the start and stabilised at about 11 bar (Figure S3) for both the solar batch and solar continuous experiment. At the end of the day the 
Rossiter, H. ; Graham, M. J. ; Schäfer, A.I. ; (2010) Impact of speciation on behaviour of uranium in a solar powered membrane system for treatment of brackish groundwater, Journal of Separation and Purification Technology, 71, 89-96.

doi:10.1016/j.seppur.2009.11.006

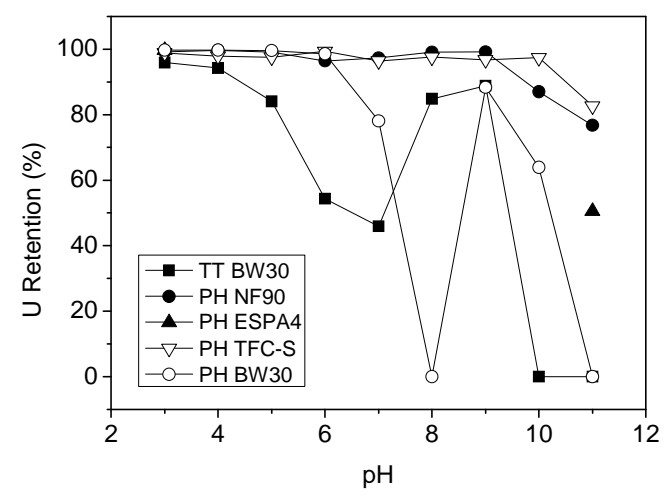

Figure S4 Retention of uranium for $\mathrm{pH}$ experiments using BW30 at Ti Tree Farm (TT) and NF90, ESPA4, TFC-S and BW30 at Pine Hill (PH).

[1] Dow Product Information: FILMTEC Membranes FILMTEC NF90 Nanofiltration Elements for Commercial Systems. http://www.dow.com/PublishedLiterature/dh_0074/0901b803800749de.pdf?filepath=liquids eps/pdfs/noreg/609-00378.pdf\&fromPage $=$ GetDoc (29 January 2009)

[2] Koch Membrane Systems: Fluid Systems TFC-S 8" Element., http://www.pureaqua.com/pdf_brands/Koch\%20TFC-S\%208.pdf (29 January 2009)
Hydranautics:
Membrane Element
ESPA4-4040.,

http://www.membranes.com/docs/4inch/ESPA4-4040.pdf (29 January 2009)

[4] Dow Product Information: FILMTEC Membranes FILMTEC Fiberglassed Elements for
Light
Industrial

http://www.dow.com/PublishedLiterature/dh_0109/0901b80380109c07.pdf?filepath=liquids eps/pdfs/noreg/609-00350.pdf\&fromPage $=$ GetDoc $(29$ January 2009) 